\title{
Case report of Actinomyces turicensis meningitis as a complication of purulent mastoiditis
}

\author{
Béla Kocsis ${ }^{1 * \dagger} \mathbb{D}$, Zoltán Tiszlavicz ${ }^{2 \dagger}$, Gabriella Jakab², Réka Brassay ${ }^{3}$, Márton Orbán $^{3}$, Ágnes Sárkány ${ }^{3}$ and Dóra Szabó ${ }^{1}$
}

\begin{abstract}
Background: Central nervous system (CNS) infections caused by Actinomyces spp. including brain abscess, actinomycoma, subdural empyema and epidural abscess are well described, however reports of Actinomycesassociated meningitis are scarcely reported.

Case report: We present the case of a 43-year-old Hungarian male patient with poor socioeconomic status who developed acute bacterial meningitis caused by Actinomyces turicensis originating from the left side mastoiditis. The bacterial cultures of both cerebrospinal fluid (CSF) and purulent discharge collected during the mastoid surgery showed slow growing Gram-positive rods that were identified by automated systems (API, VITEK) as A. turicensis The bacterial identification was confirmed by $16 \mathrm{~S}$ rRNA PCR and subsequent nucleic acid sequencing. No bacterial growth was detected in blood culture bottles after 5 days of incubation. Hence, multiple antibacterial treatments and surgical intervention the patient passed away.

Conclusions: Anaerobes are rarely involved in CNS infections therefore anaerobic culture of CSF samples is routinely not performed. However, anaerobic bacteria should be considered as potential pathogens when certain risk factors are present, such as paranasal sinusitis, mastoiditis in patients with poor socioeconomic condition. To the best of our knowledge, our case report is the first description of A. turicensis meningitis that has been diagnosed as consequence of purulent mastoiditis.
\end{abstract}

Keywords: Actinomyces turicensis, Anaerobic culture, Cerebrospinal fluid, Mastoiditis, Meningitis, Poor socioeconomic condition

\section{Background}

Meningitis caused by anaerobic bacteria is a rare disease therefore anaerobic culture of the cerebrospinal fluid (CSF) samples is not generally recommended. However, by these sparse cases of anaerobic meningitis certain conditions present risk factors namely, recurrent or chronic otitis media, brain abscess, necrotizing bowel lesions or peritonitis [1]. In cases of identifiable risk factors anaerobic meningitis should be kept in mind and the CSF specimen should be cultured both aerobically and anaerobically. The routine CSF sample processing lacks the anaerobic incubation that

\footnotetext{
* Correspondence: kocsis.bela@med.semmelweis-univ.hu

†Béla Kocsis and Zoltán Tiszlavicz contributed equally to this work.

${ }^{1}$ Semmelweis University, Institute of Medical Microbiology, Budapest, Hungary

Full list of author information is available at the end of the article
}

can lead to false-negative results and as a consequence to misdiagnose and therapy failure.

Actinomyces genus contains strictly anaerobic and aerotolerant, non-acid-fast, Gram-positive organisms with variable morphology, ranging from characteristic branching rods to coccobacilli arranged singly or in pairs. The most well-known species is Actinomyces israelii, however altogether 25 published Actinomyces species from human samples have been described [2]. Among these species Actinomyces turicensis was first reported in 1995 [3] and has been emerging as an important cause of infections [4]. A. turicensis is a non-pigment producing, aerotolerant member of Actinomyces genus. Its biochemical characteristics include negative reactions for the production of catalase, urease, $\beta$-N-acetyl-glucosaminidase and $\beta$-galactosidase, nitrate reduction, esculin hydrolysis, CAMP test and the fermentation of mannitol additionally, it produces $\alpha$-glucosidase and 
ferments maltose and sucrose. Variable reactions are raffinose and trehalose fermentation [3].

Actinomyces spp. belong to the normal bacterial flora in the oral cavity, pharynx, gut and genitourinary tract [5-10]. Actinomycosis is an uncommon infection caused by Actinomyces spp. It is characterized by an indolent, slow growing, granulomatosus disease and categorized based on the anatomical sites as orocervicofacial, thoracic and abdominopelvic forms, or in some other cases it appears as cutaneous or musculoskeletal [11-14]. Actinomyces infections of central nervous system (CNS) such as brain abscess and meningitis are rarely diagnosed [15-18]. To date no published reports of $A$. turicensis meningitis were found on online databases. We herein report the first case of $A$. turicensis meningitis that originated from the left mastoiditis and it was diagnosed in a patient with poor socioeconomic status.

\section{Case presentation}

A 43-year-old Hungarian man with poor socioeconomic living conditions was found lying on the floor unresponsively by a family member. He was taken to a regional hospital "Szent György" University Teaching Hospital, Székesfehérvár, Hungary. On admission he had low level of consciousness accompanied by stiff neck, constricted pupils and fever $\left(38.6{ }^{\circ} \mathrm{C}\right)$. Alcohol abuse, smoking and epileptic seizures were found in his past medical records. Urgent skull CT scan was performed revealing left side mastoiditis but neither brain abscess nor vascular disorders were described. Blood was drawn for clinical chemistry and for bacterial culture. Relevant parameters of the blood test showed elevated white blood cell (WBC) count 24.1 10\% / (87.5\% Neutrophils), increased C-reactive protein and procalcitonin levels $(211.4 \mathrm{mg} / \mathrm{L}$ and $0.46 \mathrm{ng} / \mathrm{ml}$, respectively). Laboratory parameters of blood and liquor are shown in Table 1. The results of the urine tests were normal.

Lumbar puncture was carried out and the CSF sample was taken to the laboratory immediately. The slightly xanthochromic CSF was cloudy showing increased WBC count $(7400$ cells $/ \mu \mathrm{l})$, elevated protein level $(12.4 \mathrm{~g} / \mathrm{L})$, and low glucose level $(<0.6 \mathrm{mmol} / \mathrm{L})$ compared to the elevated serum glucose level $(8.1 \mathrm{mmol} / \mathrm{L})$.

After taking blood and CSF specimens for culture Ceftriaxone $(2 \times 2 \mathrm{~g})$, Vancomycin $(2 \times 1 \mathrm{~g})$ and Ampicillin $(6 \times 2 \mathrm{~g})$ were started and completed with supportive treatment.

The patient's CSF sample was processed routinely in our Microbiology laboratory (SYNLAB Székesfehérvár, Hungary) on arrival. The Pastorex Meningitis agglutination kit (Bio-Rad) testing the CSF sample for the presence of soluble antigens of Streptococcus pneumoniae, Haemophilus influenzae type b, Neisseria meningitidis group A, group B/ E.coli K1, group C, group Y/W135, and Streptococcus group B was negative. Microscopic examination showed several neutrophil granulocytes and a very few number of hardly
Table 1 Laboratory parameters of blood and cerebrospinal fluid

\begin{tabular}{lll}
\hline Blood results & & \\
\hline White blood cells & $24.1 \times 10^{9} / \mathrm{L}$ & + \\
Red blood cells & $4.7 \times 10^{12} / \mathrm{L}$ & normal \\
Hemoglobin & $140 \mathrm{~g} / \mathrm{L}$ & normal \\
Neutrophil & $87.5 \%$ & + \\
Glucose & $8.1 \mathrm{mmol} / \mathrm{L}$ & + \\
Total protein & $74 \mathrm{~g} / \mathrm{L}$ & normal \\
GOT & $101 \mathrm{U} / \mathrm{L}$ & + \\
GPT & $122 \mathrm{U} / \mathrm{L}$ & + \\
GGT & $257 \mathrm{U} / \mathrm{L}$ & + \\
ALP & $221 \mathrm{U} / \mathrm{L}$ & + \\
LDH & $719 \mathrm{U} / \mathrm{L}$ & normal \\
CRP & $211.4 \mathrm{mg} / \mathrm{L}$ & normal \\
Procalcitonin & $0.46 \mathrm{ng} / \mathrm{L}$ & - \\
Liquor results & & + \\
Liquor glucose & $0.6 \mathrm{mmol} / \mathrm{L}$ & \\
Liquor protein & $12.4 \mathrm{~g} / \mathrm{L}$ & \\
\hline
\end{tabular}

dyed short rods or elongated cocci that seemed to be Gram-negatively stained at first examination. To exclude tuberculous meningitis Ziehl-Neelsen staining was performed, but no acid-fast bacilli were detected. At the 18$24-\mathrm{h}$ and $48 \mathrm{~h}$ readings bacterial growth was negative both on the blood and on the chocolate culture media. Only the enrichment broth was slightly cloudy, indicating bacterial growth. On the next day, after $72 \mathrm{~h}$ of incubation tiny grey pinhead colonies were found on both blood and chocolate agar plates that were catalase and oxidase negative. Similar colonies were seen on the anaerobic plates. Irregular small Gram-positive bacilli and coccobacilli were observed in the microscope. The bacterium was identified as A turicensis by VITEK 2 ANC ID Card (Biomerieux) and API Coryne (Biomerieux). The identification was verified by molecular method. PCR was performed with primers that amplified $1343 \mathrm{bp}$ fragment of bacterial $16 \mathrm{~s}$ rRNA coding sequence [19]. PCR thermal profile was as follows: $5 \mathrm{~min}$ at $94{ }^{\circ} \mathrm{C}, 40$ cycles of $94^{\circ} \mathrm{C}$ for $1 \mathrm{~min}, 55^{\circ} \mathrm{C}$ for $1 \mathrm{~min}$ and $72^{\circ} \mathrm{C}$ for 1 min and a final extension at $72{ }^{\circ} \mathrm{C}$ for $2 \mathrm{~min}$ [20]. PCR amplicons have been purified by Qiagen PCR Purification Kit (Qiagen, GmbH, Hilden, Germany) and have been sequenced (BIOMI Kft., Gödöllő, Hungary). Analysis of nucleic acid sequence was done based on online tools of NCBI GenBank thus, the strain was identified as $A$. turicensis.

Antibiotic susceptibility of tested strain was performed by E-test after the European Committee on Antimicrobial Susceptibility Testing (EUCAST) recommendations. The isolated strain was susceptible to penicillin, ampicillin, imipenem, meropenem and vancomycin at concentrations ranging from 0.125 to $0.5 \mathrm{mg} / \mathrm{L}$. 
As the patient's condition did not improve a left side mastoid surgery was performed. During the mastoidectomy intraoperatively removed purulent discharge was sent to our Microbiology laboratory. After two days of incubation colonies grew on the agar plates that were similar to those isolated from the CSF sample. Identification both by biochemical reactions of automated systems and by $16 \mathrm{~S}$ rRNA PCR and sequencing resulted $A$. turicensis. Moreover, the strain presented the same antibiotic MIC values as isolate of the CSF sample.

Postoperative bleeding occurred leading to the necessity of reoperation. On the third day of postoperative period severe polyuria was presented with dilated pupils insensible to light. The skull CT scan revealed cerebral herniation, intensifying oedema and sinus thrombosis. (Figures 1 and 2). Unfortunately, there was no chance of reoperation because the patient passed away.

After 5 days of aerobic and anaerobic incubation of the blood cultures no bacterial growth was detected. Autopsy was performed that confirmed the clinical diagnosis of cerebral herniation due to the purulent meningitis and the consequent oedema in the CNS. Moreover, a greenish-yellow discharge accumulated at the brain stem and in the lateral ventricules. During histopathology an infiltration of granulocytes at the

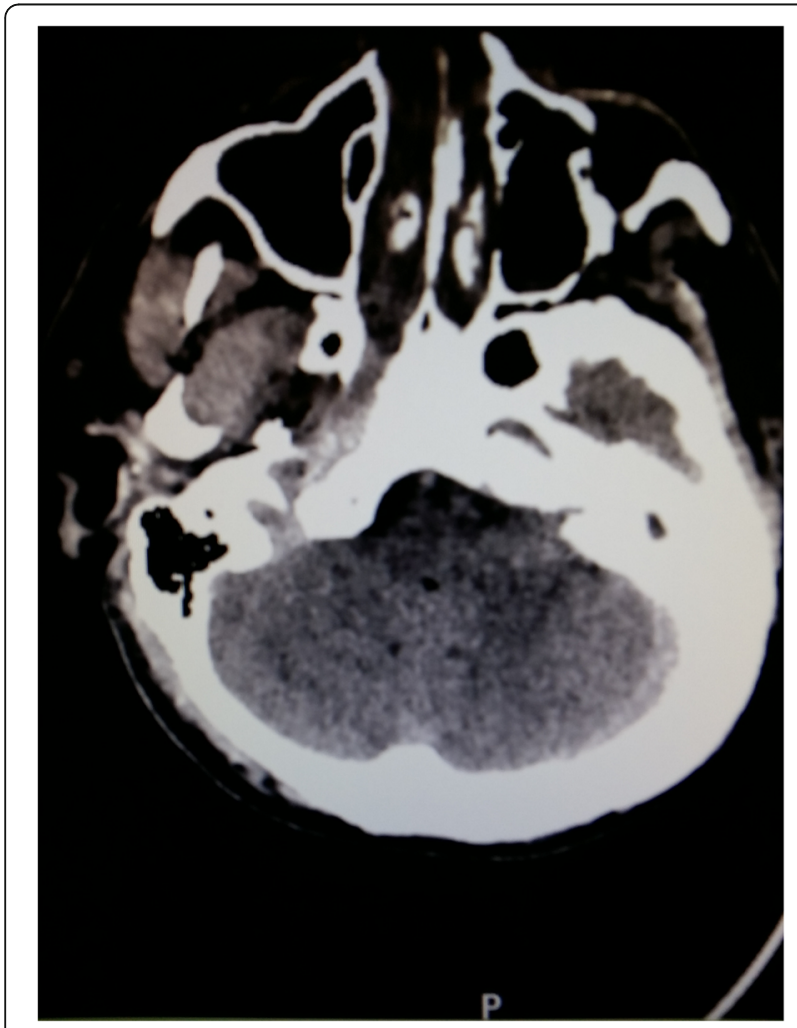

Fig. 1 Skull CT: horizontal slice of brain with left side mastoiditis

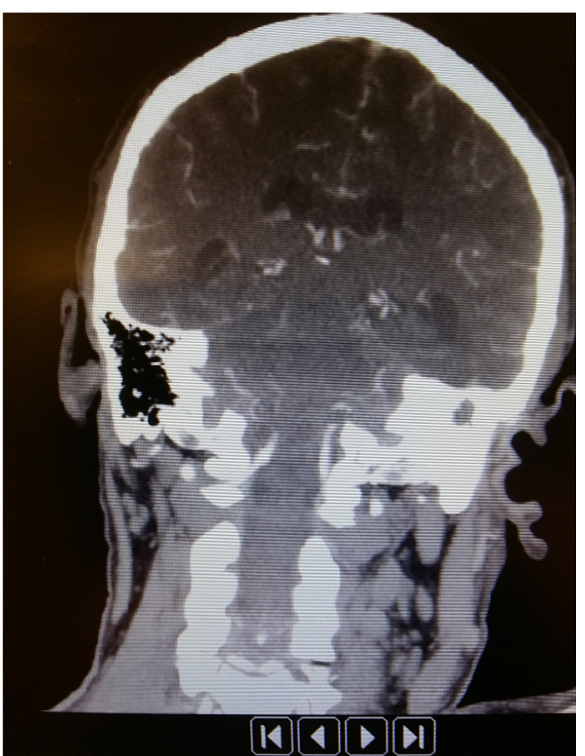

Fig. 2 Skull CT: coronal slice of brain with left side mastoiditis

meninges was seen and suspected signs of actinomycosis was also observed.

\section{Discussion and conclusions}

Actinomyces spp. resides on mucous surfaces typically in the alimentary and genital tracts. On the other hand, Actinomyces spp. can rarely cause CNS infections due to the contiguous extension of neighbouring foci, such as paranasal sinusitis, or hematogenous seeding from a distant infected site such as a dental abscess, lungs and cervicofacial region although no such apparent foci are observed in one-third of cases. The typical manifestation of Actinomyces CNS infection is brain abscess, but Smego reported that $13 \%$ of CNS lesions of actinomycosis involve meningitis [17]. A. turicensis has been described as a potential pathogen mostly in genital and skin-related infections, however here we presented a case of CNS infection, namely $A$. turicensis meningitis as a complication of purulent mastoiditis with fatal outcome. In our patient an identical $A$. turicensis strain has been identified from a purulent mastoiditis and in meningitis, indicating the invasion of the pathogen from the infectious focus to CNS. There were no signs or symptoms of lung or skin actinomycosis. Anaerobes are found to be rare causative agents of meningitis but as our case report has shown it is worth to keep it in mind as possible pathogens of CNS. It may occur in patients living in poor socioeconomic conditions (e.g: homeless and alcohol abuse) and suffering from paranasal sinusitis or inflammation of other neighbouring foci. Here, we propose the need for anaerobic cultures of CSF specimens that is essential to identify Actinomyces spp. as well as other anaerob bacteria in CNS infections. 


\section{Abbreviations}

16S rRNA: 165 ribosomal subunit ribonucleic acid: CAMP test: Christie-AtkinsMunch-Petersen synergistic heamolysis test; CNS: central nervous system; CSF: cerebrospinal fluid; CT: computer tomograph; EUCAST: European Committee on Antimicrobial Susceptibility Testing; MIC: minimum inhibitory concentration; NCBI: National Center for Biotechnology Information: PCR: polymerase chain reaction; WBC: white blood cell count

\section{Acknowledgements}

Not applicable.

\section{Funding}

This study was financially supported by OTKA Hungarian Research Fund, Grant No: 108481. The molecular biological analyses of tested strains was financially supported by funding body.

\section{Availability of data and materials}

The datasets used and/or analyzed during the current study are available from the corresponding author on reasonable request

\section{Authors' contributions}

$\mathrm{RB}, \mathrm{MO}$, ÁS managed the patient and participated in study design. ZT, G performed microbiology diagnostics, analysed and interpreted data. BK, DSZ performed molecular identification and handled the manuscript. All authors have been involved in drafting the manuscript as well as revising it. All authors read and approved the final version of the manuscript.

\section{Ethics approval and consent to participate}

Not applicable.

\section{Consent for publication}

Consent to publish was obtained from a next-of-kin after the patient's death.

\section{Competing interests}

The authors declare that they have no competing interests.

\section{Publisher's Note}

Springer Nature remains neutral with regard to jurisdictional claims in published maps and institutional affiliations.

\section{Author details}

${ }^{1}$ Semmelweis University, Institute of Medical Microbiology, Budapest, Hungary. ${ }^{2}$ SYNLAB Székesfehérvár Microbiology Laboratory, Székesfehérvár, Hungary. "Szent György" University Teaching Hospital, Székesfehérvár, Hungary.

Received: 24 August 2017 Accepted: 10 December 2018

Published online: 20 December 2018

References

1. Hawkey PM, Jewes LA. How common is meningitis caused by anaerobic bacteria? J Clin Microbiol. 1985:22:325.

2. Könönen $E$, Wade WG. Actinomyces and related organisms in human infections. Clin Microbiol Rev. 2015:28:419-42.

3. Wüst J, Stubbs S, Weiss N, Funke G, Collins MD. Assignment ofActinomyces pyogenes-like (CDC coryneform group E) bacteria to the genus Actinomyces as Actinomyces radingae sp. nov. and ctinomyces turicensissp. Nov. Lett Appl Microbiol. 1995:20:76-81.

4. Sabbe LJ, Van De Merwe D, Schouls L, Bergmans A, Vaneechoutte M, Vandamme P. Clinical spectrum of infections due to the newly described Actinomyces species A. turicensis, A. radingae, and A. europaeus. J Clin Microbiol. 1999:37:8-13.

5. Dewhirst FE, Chen T, lzard J, Paster BJ, Tanner ACR, Yu W-H, et al. The human oral microbiome. J Bacteriol. 2010;192:5002-17.

6. Sarkonen N, Könönen E, Summanen P, Kanervo A, Takala A, JousimiesSomer $\mathrm{H}$. Oral colonization with Actinomyces species in infants by two years of age. J Dent Res. 2000;79:864-7.

7. Hoyles L, Clear JA, McCartney AL. Use of denaturing gradient gel electrophoresis to detect Actinobacteria associated with the human faecal microbiota. Anaerobe. 2013;22:90-6.
8. El Aila NA, Tency I, Claeys G, Verstraelen H, Saerens B, Santiago GLDS, et al. Identification and genotyping of bacteria from paired vaginal and rectal samples from pregnant women indicates similarity between vaginal and rectal microflora. BMC Infect Dis. 2009;9:167.

9. Nikolaitchouk N, Hoyles L, Falsen E, Grainger JM, Collins MD. Characterization of Actinomyces isolates from samples from the human urogenital tract: description of Actinomyces urogenitalis sp. nov. Int J Syst Evol Microbiol. 2000;50:1649-54.

10. Lu H, Qian G, Ren Z, Zhang C, Zhang H, Xu W, et al. Alterations of Bacteroides sp., Neisseria sp., Actinomyces sp., and Streptococcus sp. populations in the oropharyngeal microbiome are associated with liver cirrhosis and pneumonia. BMC Infect Dis. 2015;15:239.

11. Smego RA, Foglia G. Actinomycosis. Clin Infect Dis. 1998:26:1255-61.

12. Wong VK, Turmezei TD, Weston VC. Actinomycosis. BMJ. 2011;343:d6099.

13. Sama CB, Mbarga NF, Oben CE, Mbarga JA, Nfor EK, Angwafo lii FF. Massive paediatric cervicofacial actinomycoses masquerading as an ulcerative malignancy. BMC Infect Dis. 2016;16:417.

14. Endo S, Mishima E, Takeuchi Y, Ohi T, Ishida M, Yanai M, et al. Periodontitisassociated septic pulmonary embolism caused by Actinomyces species identified by anaerobic culture of bronchoalveolar lavage fluid: a case report. BMC Infect Dis. 2015 Dec;15(1):552

15. Chotmongkol V, Panthavasit J, Chuesakoolvanich K. Actinomycotic meningitis: report of a case. J Med Assoc Thail. 2002;85:739-41.

16. Imamura K, Kamitani H, Nakayasu H, Asai Y, Nakashima K. Purulent meningitis caused by Actinomyces successfully treated with rifampicin: a case report. Intern Med. 2011;50:1121-5.

17. Smego RA Jr. Actinomycosis of the central nervous system. Rev Infect Dis. 1987;9:855-65.

18. Koda Y, Seto Y, Takeichi S, Kimura H. Fatal subarachnoid haemorrhage complicating actinomycotic meningitis. Forensic Sci Int. 2003;134:169-71.

19. Woo PCY, Cheung EYL, Leung K, Yuen K. Identification by $16 \mathrm{~S}$ ribosomal RNA gene sequenceing of an Enterobacteriaceae species with ambiguous biochemical profile from renal transplant recipient. Diagn Microbiol Infect Dis. 2001;39:85-93.

20. Jenkins C, Ling CL, Ciesielczuk HL, Lockwood J, Hopkins S, McHugh TD, et al. Detection and identification of bacteria in clinical samples by 165 rRNA gene sequencing: comparison of two different approaches in clinical practice. J Med Microbiol. 2012;61:483-8.
Ready to submit your research? Choose BMC and benefit from:

- fast, convenient online submission

- thorough peer review by experienced researchers in your field

- rapid publication on acceptance

- support for research data, including large and complex data types

- gold Open Access which fosters wider collaboration and increased citations

- maximum visibility for your research: over $100 \mathrm{M}$ website views per year

At BMC, research is always in progress.

Learn more biomedcentral.com/submissions 